\title{
Conflict of Interest Among Women Employees as a Threat to Business Ecosystem
}

Prof. Sheeja Krishnakumar, Assistant Professor, Research Scholar VTU,

Indian Academy School of Management Studies,

M: 9845202845, sheejak07@yahoo.co.in

\begin{abstract}
The impact of globalization and technological revolution has increased the opportunities for the women employees to work in the companies. The increased competition among the companies and the pressure to reach the target has forced the companies to give excess work load to complete within a limited time frame. This resulted in extended working hours and interference of work life into family life and from family life into work life causing conflict from both the domain. The ecosystem for a stable growth is disrupted due to these conflicting variables. For doing business a committed, enthusiastic workforce is required. This study tries to understand the personal factors and organizational factors that affect conflict among women employees. Study is related to women employees working in information technology companies. The personal factors like age, marital status from the personal side and work load and job satisfaction from organizational side towards work life conflict is tested. The study found that young married women working in information technology companies have work-life conflict more than employees belonging to the other age group. It is also found that work load and work hours are also leading to work-life conflict. So for higher commitment and job satisfaction young female employees require more support from the organization for the business ecosystem to be stable and grow.
\end{abstract}

Keywords: Age, Marital Status, Work Hours, Workload, Work-life Conflict, Ecosystem, Business

\section{Introduction}

Ecosystem for business explains about the relationship of different stakeholders for their survival. Ecosystem explains about the interaction and interconnectedness results in creating a constantly evolving relationship. Understanding the complex inter-woven relationship among varied factors of ecosystems help the organization to grow and flourish well. Each and every stakeholder's development and its contribution is very important. Employees play a major role in an organization and are the core contributor for the development of the business. So their well-being and their contribution to the company is very important.

Progression in information technology, economic development of country and increased participation of women in education has resulted in the changes in the corporate. MckinseyGlobal Institute analysis stated that twenty six percent growths can be added to the annual global GDP by 2025 if the gender parity is improved. It is understood that lot of talents are wasted without doing anything. Many educated and capable women are spending time at home without utilizing it. Organizations are trying to gain the benefit by introducing more initiatives to attract those talents into the workforce. Improved educational prospects have provided them to enter into a new world of opportunities. These chances are more for women living in the urban areas. This helped them to improve their status in the society. Improvement of financial condition in the family is another factor for the acceptance of working women in the society. Entrance 
of women folk into the organization has caused imbalance in the family structure. For most of the women it is the bringing together of the responsibilities of taking care of the family and that of work. Kahn et al. (1964, p. 19) were among first who explained role conflict as "the simultaneous occurrence of two (or more) sets of pressures such that compliance with one would make more difficult compliance with the other". Interference of family aspects into work can be believed as the outcome of imbalance between work and family life. The advancement in technology allows the work to be carried home. The boundary line between work and family life disappears and both life starts to interfere into each other's domain. Greenhaus and Beutell (1985, p. 77) explained work life conflictas a "form of inter-role conflict in which the role pressures from work and family domains are mutually incompatible in some respect, that is, participation in the work (family) role is made more difficult by virtue of participation in the family (work) role". Hsu (2011) explains that work life conflict is bi-directional. Experiences at work(e.g. longer working hours, work overload, job stress, etc.) interfere with family life and time. Experiences at home (e.g. presence of young children, marital status, elderly care etc.) interfere with work life and time.

\section{Literature Review}

The impact of the conflict was found to be more among women compared to men. Studies revealed that women take more responsibilities (Parsons \& Bales, 1955) related to family. Marriage is considered as a sacred institution in Indian context and is a union of two families (Chekki 1996) and children play a major role in the family. Marriage is the union of two families (Chekki,1996) and children pay a major role and parental role is precedence over the marital role (Rajadhyaksha 2012). Those without marriage or without children get enough time to get engrossed with the job while those with children would be bothered more about the family matters. According to (Clark,2001) job satisfaction increases with age and its effect on job satisfaction is U-shaped. The study like this in the Indian context related to women is relevant to understand her problems to contribute effectively to balance the ecosystem. Work to family interference and family to work interference were more for those employees who are married and with kids.Greenhaus and Beutell (1985) cleared in their study that inter task conflict occurred from the pressure from the respective family and work domains and were incompatible. The conflict related to work roles, work hours and work load would cause the stress to cross the boundary and cause negative behaviors to satisfy the family needs (Greenhaus et al 1987).Grandey et al. (2005) in their study suggested that when interference of work into family life exceeded, would result in dissatisfaction among the employees. As women take more responsibilities related to family they demand for child care, flexible work and work from home facilities (Hochschild, 1999). Waltman et al (2004) in his studies mentioned that women employees gain job satisfaction based on the environmental condition, departmental climate and demographics of the organization of the organization. Based on the literature surveyed the objectives framed are as follows.

\section{Objectives}

To find out the influence of personal factors like age and marital status towards work-family conflict.

To find out the influence of organizational factors like work load and work hours towards work-family conflict.

\section{Hypothesis}

$\mathrm{H} 1$ : Younger employees have higher work-life conflict than older employees.

H2: Married employees have higher work-life conflict than unmarried employees.

H3: Work load is significantly related to work-family conflict among women employees.

H4: Work hours is significantly related to work-family conflict among women employees. 
Fig. No.1 Diagrammatic Representation of the Variables under Study

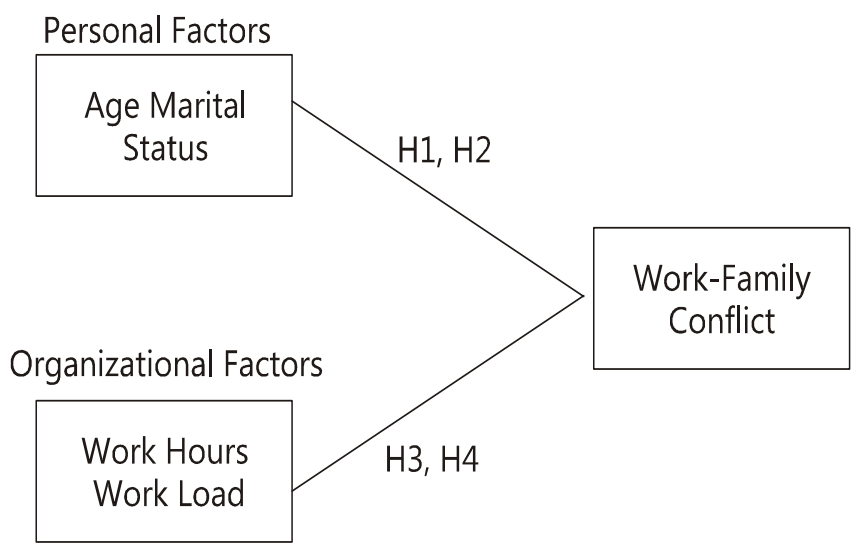

\section{Methodology}

Four information technology companies situated in Bangalore is considered for the study. The sample is collected from women employees working in information technology companies. The sample collected is 371 . Convenience sampling method is adopted to collect the data. Standardised questionnaire is used. The scale of Netemeyer (1996) is used for work-life conflict. The reliability coefficient value for this scale is .892.Steven, Minnotte, Mannon\& Kiger (2007) designed the scale of work load is considered in the study. The reliability coefficient is .841. The modified scale of Stephens and Sommer (1996) is used for work hours. The reliability coefficient value for work hours is $\mathbf{7 2 4}$. Likert scale is used. Statistical tools used for the study are Anova, Correlation and t-test. Descriptive statistics is used to summarize the large data that enable to compare across different demographics. Mean and standard deviation are also used to find the central tendency and dispersion.

\section{Analysis and Interpretation}

From the sample that is collected data is entered in the spss and analysed. It was found that majority of the women employees who participated in the study, $58.2 \%$ were in the age group of $20-30,35.3 \%$ were between the ages of $31-40$, and $6.5 \%$ in the age group
41-50. Nobody were in the age group above 50 . While examining the marital status of women employees, $62.3 \%$ respondents were married and rest of the respondents were unmarried.

Table No.1: Demographic Composition

\begin{tabular}{|l|l|l|l|}
\hline & & Count & Column N \% \\
\hline \multirow{4}{*}{ D1.Age } & $20-30$ yrs & 216 & $58.2 \%$ \\
\cline { 2 - 4 } & $31-40$ & 131 & $35.3 \%$ \\
\cline { 2 - 4 } & $41-50$ & 24 & $6.5 \%$ \\
\cline { 2 - 4 } & 51 \& above & - & - \\
\hline \multirow{2}{*}{$\begin{array}{l}\text { D3.Marital } \\
\text { status }\end{array}$} & Single & 140 & $37.7 \%$ \\
\cline { 2 - 4 } & Married & 231 & $62.3 \%$ \\
\hline
\end{tabular}

The items considered under work-family conflict are given in the table 2 .

Table No.2: Descriptive Statistics - Work -Family life Conflict

\begin{tabular}{|l|c|c|c|c|c|}
\hline & N & Min & Max & Mean & $\begin{array}{l}\text { Std. } \\
\text { Dev }\end{array}$ \\
\hline Work-Life Conflict Scale & 371 & 1 & 5 & 3.05 & 0.96 \\
\hline $\begin{array}{l}\text { WFC1.The demands of } \\
\text { your work interfere } \\
\text { with your home and } \\
\text { family life. }\end{array}$ & 371 & 1 & 5 & 3.16 & 0.92 \\
\hline $\begin{array}{l}\text { WFC2.The amount of } \\
\text { time your job takes up } \\
\text { makes it difficult to } \\
\text { fulfill your family } \\
\text { responsibilities. }\end{array}$ & 371 & 1 & 5 & 3.08 & 0.97 \\
\hline $\begin{array}{l}\text { WFC3.Things you want } \\
\text { to do at home do not } \\
\text { get done because of } \\
\text { the demands your job } \\
\text { puts on you. }\end{array}$ & 371 & 1 & 5 & 2.92 & 1.00 \\
\hline $\begin{array}{l}\text { WFC4.Your job produces } \\
\text { strain that makes it } \\
\text { difficult to fulfill family } \\
\text { duties. }\end{array}$ & 371 & 1 & 5 & 2.85 & 0.92 \\
\hline $\begin{array}{l}\text { WFC5.Due to work- } \\
\text { related duties, mostly, } \\
\text { you have to make } \\
\text { changes to your plans } \\
\text { for family activities. }\end{array}$ & 371 & 1 & 5 & 3.24 & 1.01 \\
\hline
\end{tabular}


In the analysis it was found that work-family life conflict achieved the overall mean score of 3.05. "Due to work-related duties, mostly, you have to make changes to your plans for family activities" achieved the highest mean score of 3.24. "The demands of your work interfere with your home and family life" \& "The amount of time your job takes up makes it difficult to fulfil your family responsibilities" achieved the mean score of 3.16 \& 3.08 respectively. While "Your job produces strain that makes it difficult to fulfil family duties" achieved the lowest mean score of 2.85. For all the above constructs standard deviation varied from 0.92 to 1.01 . The final mean and standard deviation of work-to-family interference is 3.05 and 0.96 .

Changing the plans for family activities due to office work related matters results in conflict. This causes less concentration on work, less job satisfaction, absenteeism and may even affect ones health.

\section{Personal Factors}

The two personal factors considered in the study are age and marital status. Different age groups are studied whereas their matrimonial status is also considered.

Table No.3 Anova for Age and T-test for Marital status

\begin{tabular}{|l|l|c|c|c|c|c|}
\hline Construct & $\begin{array}{l}\text { Demog } \\
\text { raphic } \\
\text { Variable } \\
\text { (Age) }\end{array}$ & $\mathrm{N}$ & Mean & $\begin{array}{c}\text { Std. } \\
\text { Dev }\end{array}$ & $\begin{array}{c}\mathrm{F} \\
\text { value }\end{array}$ & $\begin{array}{c}\text { Sig. } \\
\text { value }\end{array}$ \\
\hline $\begin{array}{l}\text { Work-life } \\
\text { Conflict }\end{array}$ & $20-30$ & 216 & 3.06 & 0.74 & 2.43 & 0.03 \\
\hline & $31-40$ & 131 & 3.09 & 0.90 & & \\
\hline & $41-50$ & 24 & 2.70 & 0.83 & & \\
\hline & $\begin{array}{l}51 \text { \& } \\
\text { above }\end{array}$ & Nil & & & & \\
\hline $\begin{array}{l}\text { Work-life } \\
\text { Conflict }\end{array}$ & $\begin{array}{l}\text { Marital } \\
\text { Status }\end{array}$ & $\mathrm{N}$ & Mean & Std. & $\mathrm{T}$ & Sig. \\
\hline & Single & 140 & 2.99 & 0.86 & 1.73 & 0.04 \\
\hline & Married & 231 & 3.14 & 0.71 & & \\
\hline \hline
\end{tabular}

$\mathrm{H} 1$ : Younger employees have higher work-life conflict than older women employees

The respondents of 20-30 yrs age achieved mean score of 3.06, respondents of 31-40 yrs achieved a mean score of 3.09. While respondents of $41-50 \mathrm{yrs}$ age achieved mean score of 2.70 . The $F$ value got is 2.43 and significance is 0.03 . Since the significant value is less than 0.05 , it is proved correct that the younger employees have higher work-life conflict than older employees. So there is a significant is at $5 \%$ level and the null hypothesis is rejected and the alternate hypothesis is accepted.

$\mathrm{H}$ 2: Married employees have higher work-life conflict than unmarried women employees

The single respondents have a mean score of 2.99, whereas married respondents have a mean score of 3.14. The analysis showed that the T value is 1.73 and significance is 0.04 . Since the significance value is less than 0.05 , it is proved that married employees have higher work-life conflict compared to unmarried women employees and so significant at $5 \%$ level. Hence, null hypothesis is rejected and alternate hypothesis is accepted.

\section{Organizational Factors}

The two organizational factors considered in the study are work load and work hours. The work load explains the amount of work the employees have to complete per day. The work hours explains the number of hours employees have to work to complete the work. The descriptive statistics of both work load and work hours are given below.

Table No.4 Descriptive Statistics - Work Load

\begin{tabular}{|l|c|c|c|c|c|}
\hline & N & Min & Max & Mean & $\begin{array}{l}\text { Std. } \\
\text { Dev. }\end{array}$ \\
\hline Work Load & 371 & 1 & 5 & 1.87 & 1.05 \\
\hline $\begin{array}{l}\text { WL1.You work on } \\
\text { your days off (e.g., } \\
\text { weekends) }\end{array}$ & 371 & 1 & 5 & 1.71 & 1.03 \\
\hline $\begin{array}{l}\text { WL2.Your job makes } \\
\text { personal life difficult }\end{array}$ & 371 & 1 & 5 & 1.81 & 1.05 \\
\hline
\end{tabular}


Ecosystem for Growth of Business

\begin{tabular}{|l|l|l|l|l|l|}
\hline $\begin{array}{l}\text { WL3.You neglect } \\
\text { personal needs } \\
\text { because of Work }\end{array}$ & 371 & 1 & 5 & 2.08 & 1.07 \\
\hline $\begin{array}{l}\text { WL4.You stay at work } \\
\text { after normal working } \\
\text { hours }\end{array}$ & 371 & 1 & 5 & 2.34 & 1.10 \\
\hline $\begin{array}{l}\text { WL5.You check back } \\
\text { with the office or work } \\
\text { place even when you } \\
\text { are on vacation }\end{array}$ & 371 & 1 & 5 & 1.94 & 1.22 \\
\hline $\begin{array}{l}\text { WL6.You work late } \\
\text { into the night at home }\end{array}$ & 371 & 1 & 5 & 1.74 & 1.01 \\
\hline $\begin{array}{l}\text { WL7.Cannot finish } \\
\text { your work on time } \\
\text { so carry it home. }\end{array}$ & 371 & 1 & 5 & 1.50 & 0.85 \\
\hline
\end{tabular}

From the above table it is clear that work load achieved the overall mean score of 1.87. 'You stay at work after normal working hours' achieved the highest mean score of 2.34. 'You neglect personal needs because of work', 'You check back with the office or work place even when you are on vacation' \& 'You work late into the night at home' achieved the mean score of $2.08,1.94 \& 1.74$ respectively, while 'Cannot finish your work on time so carry it home' achieved the lowest mean score of 1.5. For all the above constructs standard deviation varied from 0.85 to 1.22. The final mean and standard deviation of work load is 1.87 and 1.05 .

Table No.4 Descriptive Statistics - Work Hours

\begin{tabular}{|l|c|c|c|c|c|}
\hline & $\mathrm{N}$ & Min & Max & Mean & $\begin{array}{c}\text { Std. } \\
\text { Dev. }\end{array}$ \\
\hline Work Hours & 371 & 1 & 4.60 & 2.15 & 1.21 \\
\hline $\begin{array}{l}\text { WH1.Your work load } \\
\text { keeps you at office for } \\
\text { a long time most days. }\end{array}$ & 371 & 1 & 5 & 2.15 & 1.19 \\
\hline $\begin{array}{l}\text { WH2.You feel you work } \\
\text { more hours at office } \\
\text { and are bothering you. }\end{array}$ & 371 & 1 & 5 & 1.89 & 1.08 \\
\hline
\end{tabular}

\section{$M_{\text {ABBS }}$}

\begin{tabular}{|l|c|c|c|c|c|}
\hline $\begin{array}{l}\text { WH3.You have to miss } \\
\text { family activities due } \\
\text { to the amount of } \\
\text { time you must spend } \\
\text { on work } \\
\text { responsiveness }\end{array}$ & 1 & 5 & 2.18 & 1.04 \\
\hline $\begin{array}{l}\text { WH4.You skip lunch or } \\
\text { other breaks because } \\
\text { of less time to } \\
\text { complete more work, } \\
\text { mostly. }\end{array}$ & 371 & 1 & 5 & 1.91 & 1.12 \\
\hline $\begin{array}{l}\text { WH5.You feel you } \\
\text { spend more time in } \\
\text { commuting / travelling } \\
\text { from office to home } \\
\text { and vice versa. }\end{array}$ & 371 & 1 & 5 & 2.63 & 1.62 \\
\hline
\end{tabular}

From the table it was found that work hours achieved the overall mean score of2.15. 'You feel you spend more time in commuting / travelling from office to home and vice versa' achieved the highest mean score of 2.63. 'You have to miss family activities due to the amount of time you must spend on work responsiveness', 'You skip lunch or other breaks because of less time to complete more work, mostly', 'Your work load keeps you at office for a long time most days' achieved the mean score of 2.18, 1.91, and 2.15. 'You feel you work more hours at office and are bothering you' achieved the lowest mean score of 1.89. For all the above constructs standard deviation varied from 1.04 to 1.62 . The overall mean and standard deviation of work hours is 2.15 and 1.21.

It is clear that work load is more and they stay back to complete it and they spend more hours in travelling that is occupying much of their time.

Correlation helps to find the association between the variables considered. Here work load and work hours are tested with work-life conflict. 
Table No.5 Correlation - Organizational Factors and work-life conflict

\begin{tabular}{|l|l|l|}
\hline & & $\begin{array}{l}\text { Work- } \\
\text { LifeConflict }\end{array}$ \\
\hline Work Load & Pearson Correlation & $.478^{* *}$ \\
\hline & Sig. (1-tailed) & .000 \\
\hline & N & 371 \\
\hline Work Hours & Pearson Correlation & $.520^{* *}$ \\
\hline & Sig. (1-tailed) & .000 \\
\hline & N & 371 \\
\hline$* *$. Correlation is significant at the 0.01 level \\
\hline
\end{tabular}

The above table, it is clear that there is a relation between work load and work-life conflict and also work hours and work-life conflict. Work load and Work hours are positively related and the $r$ value is 0.478 $\& .520$ respectively. Since the significant value is less than 0.05 the constructs work load and work hours are statistically significant at $1 \%$ level.

\section{Discussion}

The ecosystem of the business can be said to be balanced only when each and every stakeholder is satisfied. Employees are the core contributor for the growth of the organization. Business ecosystem is explained as the network of organizations like suppliers, distributors, employees, customers, competitors, government agencies and so on to deliver a specific product or service. Employees who are part of the ecosystem play a major role for the future growth of the organization, especially talented women employees. For the organization to compete and grow in an innovative way well being of employees has to be taken care. Excess work load and more hours of work in the organization result in conflict of work and family life. This is proved through this study. The result of the study is also in accordance with the literature surveyed. The participation of women has proved that their contribution to the organization is inevitable. Women employees, especially young and married working in the information technology companies faces this problem. Minimum work hours of these employees are nine hours. From the study it is clear the employees whose age is between $20 \mathrm{yrs}$ and $30 y r s$ are suffering from work-life conflict more while compared to others. Those above $40 \mathrm{yrs}$ experience less conflict as the responsibilities towards home has reduced as their children would have grown big compared to youngsters. Women employees who are married experience more conflict compared to unmarried employees. Married employees may be accountable to many activities within the family and outside compared to unmarried women employees. More the work load more hours of work are required to complete the work. This causes the job related activities to penetrate into the family life. This causes conflict resulting in less satisfaction to the job. Employees being the core contributor for the growth of the organization have to be taken care for the survival and continuous growth of the organization. So a serious thought towards this issue is required and policies have to be formulated to minimize the conflict between work and family life.

\section{Conclusion}

Participation of women employees contribute much to the growth of information technology company is proved beyond doubt from some of the leading publications. In order to retain them in the company and make them work effectively, the conflict within them related to job and family life has to be minimised. The commitment towards the organization increases only by providing a helping hand to the women employees, especially who are struggling to balance work and family life. This study tries to prove that women employees find work load and work hours effecting them badly for those who are married and young. They are also part of business ecosystem and understanding their issues and solving it may contribute much to improve the complex inter-woven relationships of the factors of the ecosystem.

\section{Reference}

1) Chekki, D. (1996). Family Values and Family Change. Indian Journal of Social Work 69, 338-348. 
2) Clark, S.C. (2001). Work Cultures and Work/ Family Balance. Journal of Vocational Behavior,58, 348-365.

3) Grandey, A.A., Cordeiro, B.L., \&Crouter, A.C. (2005).A longitudinal and multi-source test of the work-family conflict and job satisfaction relationship.Journal of Occupational and Organizational Psychology, 78(3), 305-323.

4) Greenhaus, J., \&Beutell, N. (1985).Sources of conflict between work and family roles.Academy of Management Review, 10(1), 76-88.

5) Greenhaus, J.,Bedeian, A., and Mossholder, K. (1987). Work experiences, job performanceand feelings of personal and familywell-being. Journal of Vocational Behavior,31, 200-215.

6) Hsu, Y.R. (2011). Work-family conflict and job satisfaction in stress working environments:The moderating roles of perceived supervisor support and internal locus of control. International Journal of Manpower, 32(2), 233-248.

7) Kahn, R.L., Wolfe, D.M., Quinn, R.P., Snoek, J.D. and Rosenthal, R.A. (1964) Organizational Stress: Studies in Role Conflict and Ambiguity. Wiley, New York.
8) Netemeyer, R.G., Boles, J.S., \&McMurrian, R. (1996). Development and validation of work family conflict and family - work conflict scales, Journal of Applied Psychology, 81(4), 400-410.

9) Parsons, T., \& Bales, R. F. (1955). Family, socialization and interaction process. Glencoe, III: Free Press.

10) Rajadhyaksha, U. (2012). Work-life balance in South East Asia: the Indian experience. South Asian Journal of Global Business Research, 1(1), $108-127$.

11) Stephens and Sommer (1996), The Measurement of Work to Family Conflict, Sage Journals, 56(3), 155-164

12) Stevens, D.P., Minnotte, K. L., Mannon, S. E. and Kiger, O. (2007), "Examining the Neglected Side of Work Family Interface, Antecedents of Positive and Negative Family to Work Spillover", Journal of Family Issues, 28(2), 242-262.

13) Waltman, August, Louise, Jean; (2004). "Culture, Climate, and Contribution: Career Satisfaction Among Female Faculty." Research in Higher Education 45(2): 177-192. 